\title{
AN EXAMINATION OF FEEDBACK ON DRAFT ESSAYS, USING HALLIDAY'S DEFINITION OF CONTEXT
}

Lynn Quinn

Rhodes University

An historical structural understanding underpins the research reported on in this paper. The ideas of the systemic functional linguist, Michael Halliday, are used to examine a draftingresponding-redrafting process used to develop students'academic writing in the English Language for Academic Purposes (ELAP) course at Rhodes University. Using the Hallidayan framework, I examine how the process can help students adapt to the broader culture of the university and at a more micro level how the comments made by the respondent can help student writers to acquire the academic literacy required to write essays in the context of situation of the ELAP course. The features of field, tenor and mode and their associated textual meanings (that is, experiential meaning, interpersonal meaning and textual meaning) are used to categorise the ways in which comments made at the draft stage of the writing process can develop students' writing. As a result of my research I argue in this paper that it might be useful for writing consultants/lecturers to think of their feedback to students' writing in terms of these categories and to consider whether they have helped students to develop their writing by taking into account the features of the particular social context in which the writing takes place.

Die navorsing waaroor hierdie artikel verslag doen is histories-struktureel van aard. Die idees van die sistemies-funksionele taalkundige, Michael Halliday word gebruik om 'n proses vir die ontwikkeling van studente se akademiese skryfvaardighede in 'n Engels vir Ademiese Doeleindes (ELAP - English for Academic Purposes) kursus aan die Rhodes Universiteit te bestudeer. Die proses bestaan uit drie fases: studente skryf ' $n$ eerste weergawe van ' $n$ opstel, ' $n$ respondent lewerkommentaar daarop, waarna die student dan ' $n$ finale weergawe skryf. Ek gebruik Halliday se raamwerk om die wyse waarop hierdie proses studente kan help om aan te pas in die breër universiteitskultuur te ondersoek. Op 'n mikro-vlak ondersoek ek ook die wyse waarop die respndent se kommentaar die student help om die akademiese geletterdheid wat nodig is om opstelle in die konteks van die ELAP-kursus te skryf, aan te leer. Die konsepte veld (vakgebied), inhoud en vorm (field, tenor and mode) word gebruik om die maniere waarop kommentaar op die eerste weergawe van die opstelskryfproses studente se skryfvaardighede kan ontwikkel, te kategoriseer. Na aanleiding van my navorsing voer ek aan dat skryfkonsultante / dosente dit waardevol mag vind om hulle terugvoer in terme van hierdie kategorieë te beskou. Verder kan hulle besin of hulle studente gehelp het om hulle skryfvaardighede te verbeter deur die kenmerke van die spesifieke sosiale konteks waarin die skrywe plaasgevind het, in ag te neem. 
Every time a student sits down to write for us he has to invent the university for the occasion - invent the university, that is, or a branch of it, like History or Economics, or Anthropology or English. He has to learn to speak our language, to speak as we do, to try on the particular ways of knowing, selecting, evaluating, reporting, concluding and arguing that define the discourse of our community. Or perhaps I should say the various discourses of our community, since ... a student ... must work within fields where the rules governing the presentation of examples or the development of an argument are both distinct, and even to the professional, mysterious.

(Bartholomae, 1985: 134).

\section{INTRODUCTION}

In South Africa, as in most other places, many students come to university lacking the 'cultural capital' (Bourdieu, 1977) which allows them to succeed in the academic world. The term 'academic literacy' has gained common currency to describe such cultural understandings or the 'rules and conventions' (Ballard and Clanchy, 1988) shared by most academics, to which students need to conform. These understandings refer not only to textual conventions; they also define what counts as knowledge; how knowledge is constructed within the university as a whole and within specific disciplines (Boughey, 1994: 24). This understanding of academic literacy reveals a social constructivist view of the world in general and knowledge in particular and 'emphasises the cultural and social dimensions which enter into the formation and constitution of language and of texts' (Kress, 1993: 22). Geisler explains academic literacy as consisting of the content of the discipline as well as the rhetorical processes. She says

... domain content - is not a set of facts simply 'found' by the discipline ... but socially constructed by the discipline's members and intimately related to the rhetorical processes underlying the reading and writing of texts.

(1994: 211).

Many lecturers at university do not see the close connection between discipline content and rhetorical processes. They believe that it is their responsibility to 'teach' the former and that the latter will be gained through a process of osmosis. Ballard and Clanchy (1988) argue that most students benefit by having the 'rules and conventions' made explicit to them by the practitioners of the disciplines.

Many South African universities have introduced courses which are designed to help students to develop the literacy they need to cope with their academic studies. In many of these courses a process approach to developing students' writing, involving a draft-responseredraft is used. The English Language for Academic Purposes (ELAP) course at Rhodes University is no exception. At various points in the course students are required to submit drafts of their essays to which they receive constructive and formative feedback from their lecturer. ${ }^{2}$ This feedback is then used to revise their essays before a final version is submitted for assessment.

Process approaches to writing are based on research done by people like Emig $(1971,1977)$ who conducted 'think aloud' protocol analysis to reveal what 'good' writers do. For example, they identify their readers and engage in silent dialogue with those readers; they view writing 
as a recursive process requiring drafting, revising and redrafting, and so on. Process approaches to writing originally thus attempted to teach students the 'skills' used by 'good' writers. This approach to researching and understanding writing is underpinned by what Tollefson (1991) calls neoclassical understandings. A neoclassical approach to research focuses on variables within the individual. In this case, the emphasis is on the 'skills' that individual writers employ to produce good writing without taking into account the broader sociopolitical context within which the learning and writing take place. The implication of this kind of approach is a belief that learning, language acquisition and learning to write particularly are individually and voluntarily determined. It does not take into account the way social context defines appropriate ways of using language.

The way in which the process approach to developing students' writing is used in the ELAP course reflects what Tollefson (1991) calls an historical structural understanding of how students acquire academic literacy. An historical structural approach goes beyond a limited concern with individual variables to take into account the cultural context within which the writing takes place. The drafting-responding process in ELAP is thus designed to help students to acquire the academic literacies ${ }^{3}$ they need to cope with written tasks within the context of the ELAP course as well as the university as a whole. Literacies are seen as sets of practices embedded within socio-cultural contexts; not as a set of neutral, decontextualised skills.

This understanding of academic literacy as a social phenomenon rather than an individual one means that a historical structural approach has to be developed to understanding how the comments made by a respondent can 'work' to make explicit to students the writing conventions appropriate to the context. This paper reports on a piece of research intended to explore such an understanding.

The research took the form of a qualitative case-study. The case consisted of the first academic essays ${ }^{4}$ (drafts and final versions) produced by seven students, as part of their course work in the ELAP course in the first semester of 1999. Additional data was obtained by interviewing the students and the lecturer who responded to their draft essays.

The focus in my analysis of the data was on the comments made by the respondent at the draft stage and ways in which these comments helped to develop students' writing. As a result of my understanding of writing development from a social constructivist perspective (as opposed to trying to determine the skills used by individuals to develop their writing) I gravitated towards Michael Halliday's (Halliday, 1985 and Halliday and Hasan, 1985) systemic functional linguistics (SFL) as a framework for analysing the data. SFL tries to explain the ways in which language is related to its social environment. The idea of the 'autonomous text' (that writing is context-free) has been challenged by writers in many fields (for example Geisler, 1994; Street, 1995; Clark and Ivanič, 1997). It is now much more common to acknowledge that all writing is embedded in and dependent on the immediate social context in which it is written as well as the broader cultural context (Clark and Ivanič, 1997). Halliday (1985) calls these the context of situation and the context of culture (Halliday and Hasan, 1985). (See Figure 1 below). The research showed that the drafting-responding process can help students, firstly at the micro level, to develop the necessary academic literacy to cope with the demands of essay writing within the specific context of the ELAP course and secondly, that it can work to help students to adapt to the broader context of the university as a whole. In the next sections I will explore these concepts further. 


\section{THE CONTEXT OF SITUATION}

The context of situation is 'the immediate environment in which a text is actually functioning' (Halliday and Hasan, 1985: 46). The fundamental purpose of language is to make meanings and within a context of situation any text makes three types of meaning simultaneously. Halliday calls these metafunctions of language: experiential (or ideational) meanings, interpersonal meanings and textual meanings. These metafunctions are reflected by three aspects or parameters of the context of situation, namely, the field, mode and tenor of discourse. The implication is thus that there are systematic links between the organisation of language and the organisation of the context. The relationship between the two is realisational (that is, the text is used to predict the context and the context is used to predict the text) and dialogic (Macken and Slade, 1993). Experiential meaning is used to construct field, interpersonal meaning is used to negotiate tenor and textual meaning is used to develop mode (Eggins and Martin, 1997: 238-243). (These types of meaning will be further explained in the discussion section of the paper).

Underpinned by an historical structural approach to research and using the three different types of meaning with the associated features of the context, namely field, mode and tenor, I examined ways in which the respondent's comments helped students to understand how to use (in their writing) the appropriate conventions demanded by the context in which the writing took place.

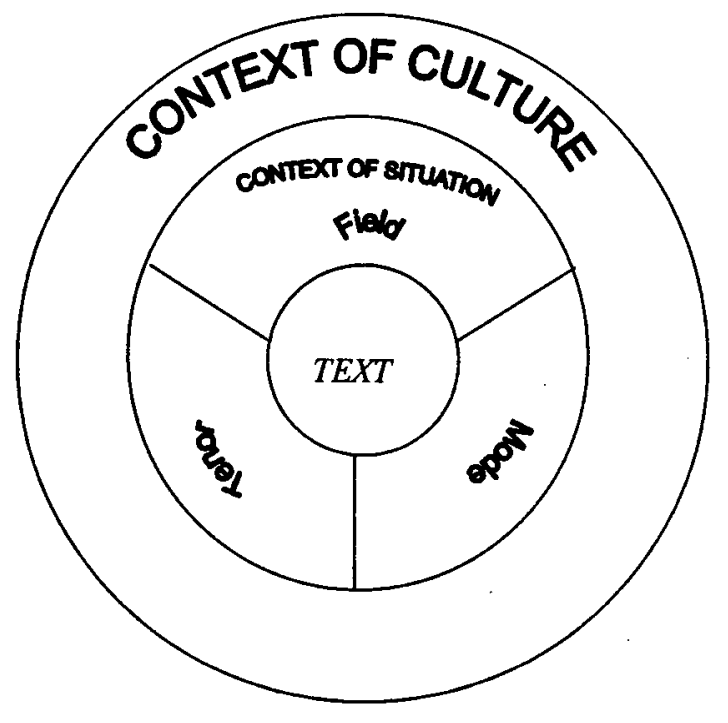

Figure 1: The relationship between text and context of situation and context of culture (based on Butt et al., 1995: 12). 


\section{THE CONTEXT OF CULTURE}

The broader context of culture shapes the various contexts of situation associated with it; the context of culture shapes the range of possibilities within a particular context of situation (Clark and Ivanič, 1997). Clark and Ivanič describe the context of culture as consisting of a configuration of values, beliefs, constructions of realities, roles and relationships - all of which are associated with various discourses and genres. In this research the context of culture is taken to be the general culture of the university which can be defined as 'the institutional and ideological background that give value to the text and constrain its interpretation' (Halliday and Hasan, 1985: 49). The immediate context of situation in which the writing took place was the ELAP course and the context of culture was the university as a whole. In my analysis of the data I examined how the ELAP tutor, through her comments on the students' draft essays helped the students to develop the academic literacy 'appropriate' to both the context of situation and the context of culture. My understanding of the acquisition of academic literacy as a process of acculturation underpins the research.

\section{RESULTS AND DISCUSSION}

The main question in my mind when I analysed the research data was: How did the draftingresponding process contribute towards the students' acquisition of academic literacy? The data is mainly discussed in terms of the context of situation: how the respondent helped students with the different kinds of meanings (that is, experiential, interpersonal and textual meanings) they were required to make in their ELAP essays. Secondly, but much more briefly, the data is discussed in terms of the context of culture: how the drafting-responding process contributed towards helping students adapt to the new culture of the university as a whole.

\subsection{Context of situation}

Table 1 below shows how the features of the context are linked to the components of the text. It also shows in brackets which aspects of the text emerged from my data and which are dealt with in this section. 5

\begin{tabular}{|l|l|l|}
\hline $\begin{array}{l}\text { SITUATION: } \\
\text { Features of the context }\end{array}$ & (realised by) & $\begin{array}{l}\text { TEXT: } \\
\text { Types of meanings }\end{array}$ \\
\cline { 1 - 2 } $\begin{array}{l}\text { Field of discourse } \\
\text { (what is going on) }\end{array}$ & $\begin{array}{l}\text { Experiential meanings } \\
\text { (conceptual development, } \\
\text { developing argument, } \\
\text { referencing) }\end{array}$ \\
\cline { 3 - 3 } $\begin{array}{l}\text { Tenor of discourse } \\
\text { (who is taking part) }\end{array}$ & $\begin{array}{l}\text { Interpersonal meanings } \\
\text { (writer's awareness of reader, } \\
\text { modality) }\end{array}$ \\
\cline { 1 - 1 } $\begin{array}{l}\text { Mode of discourse } \\
\text { (role assigned to language) }\end{array}$ & $\begin{array}{l}\text { Textual meanings } \\
\text { (integration, context, cohesion) }\end{array}$ \\
\hline
\end{tabular}

Table 1: Relation of the text to the context of situation (adapted from Halliday and Hasan, 1985: 26) 


\subsubsection{Experiential meanings (field)}

Experiential meanings refer to the 'real world'; to the field or discipline within which the writing is situated. In effect, what the text is about; how it reflects reality. For the purposes of my research I chose to discuss experiential meaning in terms of the related areas of conceptual development, development of argument and referencing. These areas are discussed in relation to how the comments made by a respondent can help a writer to make meaning.

\section{Conceptual development}

Much of the research on feedback to student writing has emphasised the importance of feedback being primarily in terms of the meaning, the concepts which the student wishes to convey in her writing (for example Ballard and Clanchy, 1988; Paxton, 1994; Sorcinelli and Elbow, 1997). In a number of the drafts examined in this research there were comments (intext and summative ${ }^{6}$ ) which aimed at helping students to understand the demands of the topic better. For example, part of the summative comment on Zamo's draft essay read:

You need to make sure that you argue clearly why Eng. should be a MOI rather than just a subject. Some of your arguments show that South Africans need to know Eng. but does this mean that they need it as MOI? Why do you think people insist that it should be a MOI? Is there some special benefit students would get? ${ }^{7}$

It is clear from his final version that there is a shift in his thinking and that he manages to focus his essay far more closely on the topic. As in the research done by Mallonee and Breihan (1985), it seems that explicit comments such as these which clearly explain the problem are more useful to students than comments like 'Stick to the topic'. In addition, the respondent asked the writer a number of questions in order to prompt him to think more deeply about the topic. A close examination of the final version showed that there was conceptual development in terms of his understanding of the requirements of the essay topic which it seems this summative comment and some of the in-text comments helped him with. In the interview Zamo remarked that these comments 'changed my whole view of the essay'.

\section{(b) Developing argument}

Writers like Lakoff and Johnson (1980), Nightingale (1988) and Moll and Slonimsky (1989) have found that very often students do not know what is meant by 'argument' when it is used to refer to academic writing, understanding it instead in terms of the metaphor of 'argument as war'. Clanchy and Ballard (in Nightingale, 1988: 65) say:

The term argument is used in a special sense in relation to academic essays. It does not mean that you must necessarily 'take sides' or present only one point of view. Rather it means that you explore the topic through clear and consistent development of ideas. using adequate evidence

There was evidence in the essays I examined of the respondent, through her comments, helping students come to an understanding of what argument is and how it is used in academic essays. In some cases her comments provided writers with a very explicit explanation of how argument can be used in academic essays, plus she gave them some vcry clear strategies for how they could go about improving their arguments. 
In the following extracts from Anathi's draft essays the respondent made a number of comments which he managed to respond to and the result was a paragraph in his final version about which the respondent said: 'Good argument through the paragraph'.

Draft:

Make it clear that you mean when English is used as an MOI

English is also a problem in South African schools because when the children who use English as a second language start school they do not have any experience in English and need to be firstly taught in their home
What do they need to understand-
Is this a contrasting point or teachers/subjects/concepts?
does it add to your argument?

language in order for them to understand. On the other hand, the first language speakers get an unfair advantage, because they are used to English from their homes, so they learn easily in their mother tongue.

This may have long term consequence...

One other example of my point here can be that in many tertiary institutions, the second language speakers of English need to first go to a certain bridging

not only the style of teaching but also language skills, which is more relevant to your essay. course to help them cope with the style of teaching in tertiary institutions; so many second language users of English need to spend an extra year at

university

varsity or college. This can be very costly because many black parents do not have enough money to pay for their children at varsity. Is this sentence relevant to the essay? Perhaps you could rather have a final sentence which points out that Eng. students are unfairly advantaged.

Final version:

English is problematic when used as a MOI in South African schools because when the children who use English as a second language start school they do not have any experience of English and need first to be taught in their home language in order for them to understand the new concepts. The first language speakers of English have an unfair advantage when English is used as a MOI because they are used to English, so they learn more easily in their mother tongue. This may have long term consequences e.g. when students reach university they will need to attend a bridging course because they used English as a second language and therefore they have to spend an extra year at university or college in order to learn the language skills which are required from them in tertiary institutions.

It seems that the respondent's comments encouraged Anathi to rethink his argument in this paragraph. His argument in the final version was more coherent and did not contain ideas that were irrelevant to the topic. He seemed to have done more than mechanically copy suggestions made by the respondent. Once again, possibly the questioning format and posing of alternatives prompted him to think about the issues raised by the respondent. 
In the interviews I conducted with the students they all said that the major difference for them from the kind of writing they did at school and university essays is that in the latter they are required to seek ideas from sources (that is, not just write from 'common knowledge') and then reference the ideas. Using sources and referencing in academic writing thus has a strong epistemological basis: knowledge is constructed through using the ideas of others as evidence for the writer's own ideas. Knowing how and when to reference is vital for student writers to learn, in terms of the 'rules' of building knowledge in the field.

There was some evidence in the essays I examined of the respondent's comments on referencing encouraging students to go back to the readings which they had done, resulting in improved conceptual understanding and/or improved arguments.

For example, Tsakani's draft did not contain a single in-text reference to another writer. The respondent pointed to this both in the text and in her summative comment. In the text she said things like: 'These are very general ideas which seem to be based on your own opinion. You should see if there is a reference to support you here', 'Do you have a reference for this point? Where did you find this information?', 'I think this is Rangaka's point so you need to reference it', (plus another six comments related to referencing). In her summative comment she said, 'Make sure you reference all ideas/arguments that are not originally your own'. In the final version Tsakani added 22 references, that is, name of author and date of publication. She seemed to have understood why this was necessary and complied with the requests in the draft. A further development for this student will be when she is better able to integrate the information from sources and to use quotations, and so on.

\subsubsection{Interpersonal meaning (tenor)}

Interpersonal meanings are linked to the dimension of tenor which refers to the social role relationships played by the participants (for our purposes this is the writer-reader relationship). Part of the purpose of feedback on draft essays is to help the student to have a clearer understanding of the writer-reader relationship in order to understand fully what is involved in writing (Clark and Ivanič, 1997). It is also to help students to see how their language choices convey their feelings and attitudes (towards the field and the reader) and how they might better control the identity and attitudes they want to reveal (Ivanič and Simpson, 1992). In my research I used this category to examine how the tutor helped the students to be more conscious of the audience for their writing and secondly to use modality. which is one of the ways in which writers can express their relationship. with their readers and the field of the essay.

(a) Making the writer aware of the reader

In the essays I examined there were a number of examples of the respondent explicitly reminding writers that they need to be aware of their readers. For example, part of Anathi's introduction to his draft essay read:

In my argument in this essay I am going to discuss both the advantages of using English as a medium of instruction and also the disadvantages but $\mathrm{I}$ am in favour of this 'against arguments'. 'not having English as the MOI' - this is clearer than making the reader re-read what the argument is about. 
Through this comment the respondent clearly reminded the writer of the need to be as clear as possible in order to help the reader and she also gave him a clear suggestion for how he could rephrase that section of the sentence.

Linked to the above point is the issue of writers positioning readers. In Zamo's draft essay he said:

As we all know nowadays S.A. is an internationally recognised country.

You actually have to prove this - you cannot assume something like this in an academic essay. If you just started with 'nowadays' then you turn it into a statement that your reader can disagree with and you are not forcing him or her to accept what you have assumed, i.e. the statement can be debated.

Through this comment the respondent was highlighting an important convention in academic writing. In the interview with Zamo he seemed to understand that the way he had phrased it, he was assuming that everyone believed the same as he did but that in academic writing that is not usually acceptable.

(b) Modality

One of the criteria for general academic writing which Johns (1997: 60) mentions is that writers should take a 'guarded stance' in academic writing. The most common way of 'hedging' or showing 'tentativeness' in writing is through the use of modals.

There were some examples from the essays with comments which showed students how 'tentativeness' is used in academic writing.

Firstly, because business in South Africa has always been in the hands of the english, and there is no way a person can get a job if they do not know how to speak and write english competently ... (Kgaogelo)

Are you sure this is true? Aren't there many people in SA who have jobs but don't speak/write English? Be careful of being too definite.

By using the questioning format in the comment, the respondent was trying to use a 'facilitative' rather than a 'directive' method of responding (Sommers, 1982 and Brannon and Knoblauch, 1982). She wanted the writer to think about the assumptions which she had made without telling her how she should change her essay. When the respondent examined this part of the data she said, 'I particularly like to use the question format here so that students become aware of the fact that the world does not only operate according to their beliefs or views'. In the last sentence though she warns Kgaogelo quite explicitly against being too definite. In the final version Kgaogelo changed 'there is no way' to 'the chances are slim that'. In the interview she indicated that she understood the need to be more tentative but she still felt that her statement was correct for the majority of cases.

\subsubsection{Textual meaning (mode)}

Eggins describes textual meanings as 'the way the text is organised as a piece of writing (or speech)' (1994:12). The situational variable associated with it is mode. Whereas field is the what of text, tenor is the who of text, mode is the how of text; mode is the role played by language. For many novice writers a major stumbling block is realising that oral and written discourses do very different things and that academic writing requires a special kind of literacy which they need to acquire in order to become 'experts' in their various disciplines. 
In my research I examined some of the ways in which the respondent helped students with the written mode in terms of their ability to integrate their ideas better in their essays (Chafe and Tannen, 1982 and 1985). Using Tannen's concept of relative focus on interpersonal involvement $\mathrm{I}$ then looked at how the respondent reminded writers to assist their readers by providing explicit contexts for the ideas they presented and finally how the respondent encouraged writers to use cohesive devices to help readers negotiate meaning.

\section{(a) Integration}

If one thinks of face-to-face conversation as being on one end of a continuum and traditional academic essays (or expository writing) as being on the other end, then according to Chafe (1985), academic writing should have a highly developed integrated quality as opposed to speech, which is more fragmented. For academic writing to have an integrated quality it helps if the writer has chosen appropriate formal and precise language in which to express her ideas. If the language used is too informal and vague, the writing will have the fragmented quality of spoken discourse. Part of learning to write academic essays means learning to write in the discourse of the discipline. It is most likely that in ELAP, and particularly in the first part of the academic year, this simply means helping students to see the difference between the spoken and written mode and encouraging them to write in a more integrated, formal and academic way.

In Zamo's draft the respondent made a general comment, 'Be careful of being too informal and writing as you speak. You need to be as formal as possible'. Although she didn't provide any particular in-text examples for him, the general tone of his final version was more formal, less 'chatty'. This was evident, for example, in the greater use of cohesive devices, more referencing and the omission of phrases like 'I say this because...', You find that a small group...', 'As I have mentioned...', and so on.

\section{Context}

In academic writing the focus is much more on the content that is being conveyed than on the interpersonal involvement of the writer and reader. In speech the interactants use the immediate context to help them construct meaning. In writing it is up to the writer to provide an explicit context for the reader within the text (Macken and Slade, 1993). Clark and Ivanç (1997) point out that this is especially difficult for students in academic writing because at one level they are writing for 'experts' in the disciplines but at another level they are expected to display their knowledge and understanding in their writing.

Boughey (1995: 204-205), using the ideas of Cummins (1984) believes that comments made by a respondent can help students make the transition from using language in a context dependent way 'towards an understanding of language as a mode of communication which can be used to communicate meanings independent of the context in which they were originally constructed and without the support of para-linguistic features for the communication of those meanings'.

There were some examples in the essays of the respondent helping writers to become more aware of the reader's need in terms of context. For example, the first line of Anathi's draft essay read: 
This is a very critical topic; because many people have different ideas about language... You shouldn't assume that your reader knows what the topic is.

In this example the respondent reminded him to be aware of the needs of the reader but she didn't tell him how to revise. In the final version he stated the topic clearly:

My topic about English being used as a medium of instruction at school in present day South Africa is...

\section{(c) Cohesion}

Coherence refers to the way the text 'hangs together' so that a specific reader in a specific context can understand it. It consists of two levels: firstly, coherence as a property of interpretation and secondly, as a property of text, that is, internal coherence using cohesive devices (Halliday and Hasan, 1976). This section deals with the use of internal cohesive devices. According to Tannen (1985), providing cohesive ties is an important aspect of expository text because of the relative lack of focus on interpersonal involvement in that discourse. Cohesion has to be lexicalised in written text rather than conveyed through paralinguistic and prosodic cues as in spoken discourse. Another of the general features of academic text outlined by Johns is:

Writers should provide 'maps' or 'signposts' for the readers throughout the texts; telling the readers where they have been in the text and where they are going.

(1997: 59)

She goes on to say that through these a writer can help a reader to predict and summarise a text as well as understand the relationships among ideas and arguments. Cohesion is one aspect of academic writing with which a respondent can very easily assist students. There were many examples amongst the essays I examined. For example, a part of the summative comment on Zamo's draft was:

Your paragraphs are usually well developed, i.e. the topic progresses logically and you keep to a single topic. The final, summarising sentences are also good. However, you could guide the reader more clearly through your essay by using cohesive devices at the beginning of each paragraph.

The first two sentences of the comment served two purposes: firstly they provided positive feedback to the writer and secondly they made explicit to him what he might be doing intuitively, thus providing him with useful metacognitive understanding of his own strategies. The respondent was pointing out to him that there was coherence in his writing but that it could be improved by providing more cohesive devices. In terms of the use of cohesive devices there was a marked development from the first to the final draft. In the first draft there were no cohesive devices whereas the development of the writer's argument was clearly signposted in the final version.

Having examined the data at a deeper level in terms of the linguistic model of the context of situation, I will now look at it from the broader perspective of the context of culture. There is no separate linguistic model for the context of culture (Halliday and Hasan, 1985) but it is important when looking at students' texts to be aware of how the beliefs, values, assumptions 
and so on of the context of culture, that is, the university generally, influence what is deemed 'appropriate'/ acceptable in the context of situation.

\subsection{Context of Culture}

Research done at South African universities has shown that many students, but particularly those from ex-Department of Education and Training (DET) backgrounds, struggle with the culture of the university. For example, research done at the University of Cape Town reported on by Hutchings (1998) found that there are wide differences between the culture of the university and the cultures that ex-DET students come from in terms of learning, knowledge and writing; students reported feeling 'academic intimidation' and alienation. The role of the ELAP course generally and the feedback to essays specifically is to help students with the 'unsteady transition between cultures' (Ballard and Clanchy, 1988: 13) in terms of their academic writing.

The ELAP students who participated in this research claimed never to have written 'academic' essays at school. They were seldom required to read anything in preparation for an essay (other than the prescribed textbook in content subjects) or to reference and if they were it was only in the form of a bibliography at the end of the essay. Zamo says: 'We didn't have to do much research on it. It's like you had to write it from your head'. Kgaogelo talks of the history teacher giving them notes which they used to write essays and she says 'the ideas were the ones which we were being taught' which seems to indicate an attitude to knowledge as something fixed, 'out there' which simply has to be recorded in an essay. They were required to use 'knowledge telling' strategies as opposed to the 'knowledge transforming' strategies which more skilled writers use (Bereiter and Scardamalia, 1987).

In their interviews some of the students said that the most valuable aspect of having had the opportunity to take part in the drafting-responding process was that they felt more confident that they were on the right track. Having to do a draft gave them the confidence to experiment because they knew that they would have a 'second chance'.

The respondent tried, wherever possible, to give the students positive feedback, especially in places where a student had responded to a particular aspect of writing which had been dealt with as part of the ELAP curriculum. She provided positive feedback, by giving what Elbow calls, 'descriptive or observational responses' (1997: 10). This could help students to develop a metacognitive understanding of the writing and thinking processes they had used (also Ely et al., 1997). Paxton believes that the role of feedback on writing fits somewhere between encouraging acquisition of discourse (that is, through interacting with those who have already mastered the discourse) and learning (that is, 'metalevel' knowledge) but for the feedback to be successful it 'needs to be constructive and not reinforce negative perceptions students might have about their writing' (1998: 150). Tsakani, for example, made particularly good use of cohesive devices which the respondent pointed out throughout the essay ( $\checkmark$ good) and at the end, 'Excellent use of cohesive devices'. At the end of a paragraph the respondent wrote:

Generally a well structured paragraph where ideas are linked and you keep to one topic.

It is possible that this type of comment might help make explicit to a student what has been taught about paragraph structure in the ELAP course. This is an extract from the interview 1 did with Tsakani: 
Lynn: Did it help you where your argument isn't clear? You know, if you look at a paragraph where your argument is clear?

Tsakani: Yes, it does because it helps me go through my paragraph again and try to go through the points and the ideas that I wrote to correct those paragraphs that she says she doesn't understand.

Tsakani sums up her feelings about positive comments:

Because if someone tells you, you are dumb, dumb every time you tend to think that. When she tells you that at least you did something right, you tend to want to improve and do more right than wrong...

\section{CONCLUSION}

Finally, what has emerged most strongly for me in the course of this research and my work with students' writing is how much we expect of students. Referring back to the quotation with which I began this paper - we expect students 'to speak our language, to speak as we do, to try on the particular ways of knowing, selecting, evaluating, reporting, concluding and arguing that define the discourse of our community' (Bartolomae, 1985: 134). This research has shown that the drafting-responding process, as it is used in the ELAP course at Rhodes University, can help students to begin the process of learning 'to speak our language', but for students to become full members of any discourse community, lecturers in all disciplines have to take on the task of helping students to acquire the literacies they need to cope with their academic tasks.

I believe that lecturers often respond inappropriately to their students' writing and that by learning to focus on the features of the immediate context in which the writing is taking place, that is, the field, mode and tenor in their comments they are more likely to make explicit to students the 'rules and conventions' (Ballard and Clanchy, 1988) of their disciplines:

Becoming literate involves becoming acculturated: learning to read and write the culture. For academic wishing to hasten the process, the key to success lies in developing practical ways of making their own understanding of the university culture explicit and accessible to their students.

(Ballard and Clanchy, 1988: 19) 


\section{END NOTES}

1 The ELAP course was introduced to Rhodes University in 1994 in response to increasing student diversity, in terms of cultural, socio-economic and linguistic backgrounds as well as levels of underpreparedness for university. It is a one-year credit-bearing course for students from the Commerce, Humanities and Science faculties. The majority of students who do ELAP speak English as a second of even third language.

${ }^{2}$ The ELAP lecturer is often referred to as the respondent in the paper.

${ }^{3}$ Understanding academic literacy involves learning what knowledge is acceptable in a particular discipline (how that knowledge is constructed) as well as how to express that knowledge in ways that are acceptable to the 'experts' in the disciplines.

${ }^{4}$ The topic for the first ELAP essay was: Discuss the arguments for and against the use of English as medium of instruction in school in present-day South Africa.

${ }^{5}$ For the sake of brevity, I have included in the discussion one example of each category to exemplify ways in which 1 think the drafting-responding process worked well. The research on which this paper is based does include a more critical examination of the drafting-responding process and discusses examples of when the process did not succeed but for the purposes of this paper I have focused on evidence which confirms the validity of using "field", "mode" and "tenor" to explore comments made by a respondent.

${ }^{6}$ Some researchers (for example, Sorcinelli and Elbow, 1997) believe that comments that focus on a particular point in the text (in-text comments) as well as more general comments at the end of the essay (summative comments) are useful but there needs to be a clear relationship between the two types of comments. Summative comments can provide an overview of the text and give cohesion to in-text comments.

${ }^{7}$ The respondent's comments are represented in the text in smaller font italics.

\section{ACKNOWLEDGEMENTS}

I would like to thank the seven ELAP students: Anathi, Zamo, Ashley, Phumlani, Loyiso, Tsakani and Kgaogelo and their ELAP tutor, Carol Hobson, for participating so willingly in my research. In addition, I would like to thank Chrissie Boughey, Director of the Academic Development Centre at Rhodes University, for her on-going support and advice both in terms of my research and the writing of this paper.

\section{REFERENCES}

BALLARD, B AND J CLANCHY. 1988. Literacy in the university: An 'anthropological' approach. In Taylor, G, B Ballard, V Beasley, V Bock., J Clanchy, \& P Nightingale (Eds), Literacy by degrees. Milton Keynes: SRHE and Open University Press: 7-23.

BARTHOLOMAE, D. 1985. Inventing the university. In Rose, M (Ed.), When a writer can't write: studies in writer's block and other composing-process problems. New York: Guilford.:134-165.

BEREITER, C AND M SCARDAMALIA. 1987. The psychology of written composition. Hillsdale, NJ: L. Erlbaum. 
BOUGHEY, C. 1994. New meanings for old words: Defining and developing academic literacy at South African universities. In Proceedings of the $9^{\text {th }}$ Annual Conference of the South African Association for Academic Development, Vol. 2, University of Natal, Durban:2-29.

BOUGHEY, C. 1995. The UNIZUL writing respondent programme: An alternative to a writing centre. In Proceedings of the $10^{\text {th }}$ Annual Conference of the South African Association for Academic Development. Technikon Free State, Bloemfontein:201209.

BRANNON, L AND CH KNOBLAUCH. 1982. On students' rights to their own texts: A model of teacher response. In College Composition and Communication, 33:157-166.

BOURDIEU, P. 1977. Outline of a theory of practice. Cambridge: Cambridge University Press.

BUTT, D, R FAHEY, S SPINKS \& C YALLOP. 1995. Using functional grammar: An explorer's guide. Sydney: MacQuarrie University.

CHAFE, WL. 1982. Speaking, writing and oral literature. In Tannen, D (Ed.), Spoken and written language: Exploring orality and literacy. New York: Ablex:35- 53.

CHAFE, WL. 1985. Linguistic differences produced by differences between speaking and writing. In Olson, D, N. Torrance \& A. Hildyard (Eds.), Literacy, language and learning: The nature and consequences of reading and writing). Cambridge: Cambridge University Press:105-123.

CLARK, R AND R IVANIČ. 1997. The politics of writing. London and New York: Routledge.

EGGINS, S. 1994. An introduction to Systemic Functional Linguistics. London: Pinter.

EGGINS, S AND JR MARTIN. 1997. Genres and registers of discourse. In van Dijk, TA (Ed.), Discourse as structure and process. London: Sage:230-256.

ELBOW, P. 1997. High stakes and low stakes in assigning and responding to writing. In Sorcinelli, MD \& P. Elbow (Eds.), Writing to learn: Strategies for assigning and responding to writing across the disciplines. San Francisco: Jossey-Bass:5-15.

ELY, M, R VINZ, M DOWNING, \& M ANZUL. 1997. On writing qualitative research: Living by words. London: Falmer.

EMIG, J. 1971. The composing processes of twelfth graders. Urbana, IL: National Council of Teachers of English.

EMIG, J. 1977. Writing as a mode of learning. In College Composition and Communication.

GEISLER, C. 1994. Academic literacy and the nature of expertise. Hillsdale, New Jersey: Lawrence Erlbaum. 
HALLIDAY, MAK. 1985. Introduction to Functional Grammar. London: Edward Arnold.

HALLIDAY, MAK AND R HASAN. 1976. Cohesion in English. London: Longman.

HALLIDAY, MAK AND R HASAN. 1985. Language, context, and text: Aspects of language in a social-semiotic perspective. Oxford: Oxford University Press.

HUTCHINGS, C. 1998. Transitional barriers and contextual gaps in an academic department. In Angelil-Carter, S (Ed), Access to success: Literacy in academic contexts. Cape Town: University of Cape Town Press:103-119.

IVANIČ, R AND J SIMPSON. 1992. Who's who in academic writing? In Fairclough, N (Ed.), Critical language awareness. London: Longman:141-173.

JOHNS, AM. 1997. Text, role, and context. Cambridge: Cambridge University Press.

KRESS, G. 1993. Genre as social process. In Cope, B \& M. Kalantzis (Eds.), The powers of literacy: A genre approach to teaching writing. London: Falmer: 22-37.

LAKOFF, G AND M JOHNSON. 1980. Metaphors we live by. Chicago: University of Chicago Press.

MACKEN, M AND D SLADE. 1993. Assessment: A Foundation for Effective Learning in the school context. In Cope, B \& M. Kalantzis (Eds.), The powers of literacy: A Genre approach to teaching writing. London: Falmer:203-230.

MALLONEE, BC AND JR BREIHAN. 1985. Responding to students' drafts: Interdisciplinary consensus. College Composition and Communication, 36(2): 213-231.

MOLL, I AND L SLONIMSKY. 1989. Towards and understanding of cognition and learning in the academic support context. South African Journal of Higher Education, $3(1): 160-166$.

NIGHTINGALE, P. 1988. Language and learning: a bibliographic essay. In Taylor G, B. Ballard, V. Beasley, V. Bock, J. Clanchy \& P. Nightingale (Eds.), Literacy by Degrees. Milton Keynes: Open University Press.

PAXTON, M. 1994. Case studies of tutors' responses to student writing and the way in which students interpret these. Thesis submitted in partial fulfillment of the requirements for the Degree of Master of Education. Rhodes University.

PAXTON, M. 1998. Transforming assessment practices into learning processes. In AngelilCarter, S (Ed.), Access to success: Literacy in academic contexts Cape Town: University of Cape Town Press:136-158.

SOMMERS, N. 1982. Responding to student writing. College Composition and Communication, 33 (2):148-156. 
SORCINELLI, MD AND P ELBOW. 1997. (Eds). Writing to learn: Strategies for assigning and responding to writing across the disciplines. San Francisco: Jossey-Bass.

STREET, BV. 1995. Social literacies. London and New York: Longman.

TANNEN, D. 1982. The Oral/literate continuum in discourse. In Tannen, D (Ed.), Spoken and written language: Exploring orality and literacy. New York: Ablex:1-16.

TANNEN, D. 1985. Relative focus on involvement in oral and written discourse. In Olson, D, N Torrance \& A Hildyard (Eds), Literacy, language and learning: The nature and consequences of reading and writing. Cambridge: Cambridge University Press:124147.

TOLLEFSON, JW. 1991. Planning language, planning inequality: Language policy in the community. London: Longman.

\section{Bibliographic Note}

Lynn Quinn has been involved in the field of Academic Development in Higher Education since 1994. Her earlier work was in helping lecturers to develop their students' academic writing but now her interests have moved more broadly to general staff development. At present she is involved in facilitating and researching a post graduate certificate course in higher education for lecturers at Rhodes University. 